\title{
Review and update of the Hong Kong Epilepsy Guideline on status epilepticus
}

\author{
Eva LW Fung, Ben BH Fung *; Subcommittee on the Consensus Statement of The \\ Hong Kong Epilepsy Society
} elp to determine the most effective treatment for benzodiazepine-resistant status epilepticus. cy that requires prompt and appropriate
Treatment of convulsive status Treatment of convulsive status
ticus is usually divided into stages/steps. The definition of status epilepticus that may to unify the definition in future studies. Over last few years new information has become the last few years new information has become
available regarding its management. The Rapid
Anticonvulsant Medication Prior to Arrival Trial
demonstrated non-inferiority of intramuscular
midazolam in early status epilepticus compared with
intravenous lorazepam. Valproate and levetiracetam
have also emerged as possible alternatives to
phenytoin in established status epilepticus. The 


\section{對香港腦㾫指引中抽搐性腦疡持續狀態的 回顧及更新 \\ 馮麗華、馮斌熙；香港腦痭學會共識聲明附屬委員會}

抽搐性腦癇持續狀態 ( SE ) 是腦痌最極端的狀態, 亦是神經系統 疾病中要緊急處理的情況, 必須輔以及時和適當的治療。現時一 般的指引建議分階段、有步驟地治理此症。近年國際抗癲癇聯盟 （International League Against Epilepsy）發布對SE的新定義, 有助 未來研究統一定義。過往幾年出現很多有關治理 SE的研究和新資 訊。Rapid Anticonvulsant Medication Prior to Arrival Trial研究發現 早期SE中, 肌注咪唑安定（midazolam）的療效不下於靜脈注射勞 拉西泮（lorazepam）。臨床數據也發現丙戊酸鈉（valproate）和左 乙拉西坦 (levetiracetam) 可於確定性腦癇持續狀態中替代苯妥英鈉 （phenytoin）。克膜衣錠（lacosamide）在這階段的SE的潛在應用仍 有待確定。正在進行的Established Status Epilepticus Treatment Trial 研究將有助找出最有效治療抗苯二氮卓類 (benzodiazepine-resistant) 病例的藥物。難治性SE和超難治性SE的治療仍是非循證的。近年的 研究發現自身免疫性病也可導致超難治性SE, 所以免疫調節治療被廣 泛使用。在這極具挑戰性的狀況下使用氯胺酮治療也日趨普遍。本文 也報導利用生酮飲食和鎂等治療超難治性SE的潛在用途

\section{Early status epilepticus}

Early treatment of SE by paramedics reduces the number of patients with a persistent seizure state on arrival at the emergency department and admission to the intensive care unit. ${ }^{6}$ In the past decade, several studies have evaluated the efficacy of different benzodiazepines in early SE. The RAMPART (Rapid Anticonvulsant Medication Prior to Arrival Trial) was a randomised, double-blind, phase 3 , noninferiority clinical trial. It involved 4314 paramedics in 33 emergency medical service agencies and 79 hospitals across the United States. In this trial, a total of 893 subjects were randomised and treated. They were children with an estimated body weight of $\geq 13 \mathrm{~kg}$ and adults with $>5$ minutes of convulsions who were still seizing upon arrival of paramedics. A fixed dose of midazolam administered by intramuscular (IM) autoinjector was found to be at least as safe and effective as intravenous (IV) lorazepam. Patients treated with IM midazolam were more likely to have stopped seizing on arrival at the emergency department, and less likely to be hospitalised or admitted to an intensive care unit.?

Previous studies have shown that lorazepam is superior to diazepam in early $\mathrm{SE}^{,}{ }^{8}$ but this may not apply to paediatric patients. In a double-blind, randomised clinical trial in 273 paediatric patients, lorazepam was reported to be only comparable with diazepam in terms of efficacy and safety in early SE. ${ }^{9}$

Other trials have also attempted to study the role of non-benzodiazepines in early SE. In a recent trial, addition of levetiracetam (LEV) to clonazepam had no advantage over clonazepam alone in the control of generalised CSE before admission to hospital. ${ }^{10}$ In another randomised, open-label study comparing IV LEV $20 \mathrm{mg} / \mathrm{kg}$ over 15 minutes with lorazepam $0.1 \mathrm{mg} / \mathrm{kg}$ over 2 to 4 minutes in patients with early SE, both regimens were equally effective. Lorazepam, however, was associated with a significantly higher need for artificial ventilation and insignificantly higher frequency of hypotension. Nonetheless, this was an open-label pilot study that involved only 79 patients. ${ }^{11}$ The role of LEV in early SE remains to be defined.

In summary, benzodiazepines are used in the initial management of SE. As well as IV lorazepam and diazepam, IM midazolam is an effective and safe parenteral alternative. Buccal/intranasal midazolam or rectal diazepam can be considered as well, although the former is still not registered in Hong Kong. It should be stressed that initial therapy should be given at an adequate single full dose rather than broken into multiple smaller doses. Repeated doses of benzodiazepines are associated with a higher risk of respiratory depression but less efficacious than first dose..$^{12}$ In-vitro studies have demonstrated that SE results in a decrease in the phosphorylation of $\gamma$-aminobutyric acid (GABA) type A receptor $\beta 3$ subunits by protein kinase $C$. This leads to reduced synaptic inhibition, that is, increased excitatory drive and a lower seizure threshold as well as decreased benzodiazepine sensitivity. ${ }^{13}$

\section{Established status epilepticus}

In most guidelines or protocols for management of SE, after failure of benzodiazepines (in one or two adequate doses), a second AED will be employed. Phenytoin or phenobarbital have been widely used in the territory, largely based on the recommendations of the Veterans Affairs Status Epilepticus Cooperative Study. ${ }^{14}$ Subsequently further properly controlled trials to support other treatment options for established SE and RSE have not been carried out.

Over the past decades, there have been many reports on the use of IV valproate (VPA) in treating SE following benzodiazepine failure. There are also case series that report the use of newer AEDs with IV formulations, eg LEV. . $^{15-22}$

Despite the lack of good randomised controlled trials, in a recent meta-analysis, the uses of IV lacosamide, LEV, VPA, phenytoin, and phenobarbital were compared. It found that LEV, VPA, and phenobarbital were comparable in terms of efficacy in stopping benzodiazepine-resistant SE. ${ }^{23}$ Yet the evidence does not support the use of phenytoin despite its continued and common use. There is insufficient evidence to support the routine use of lacosamide and it was excluded from the metaanalysis. The conclusion highlighted the urgent need 
for randomised controlled trials in this scenario. ${ }^{23}$

\section{Valproate}

With an IV formulation available since 1993, VPA is a broad-spectrum AED effective against all seizure types. $^{24,25}$ The exact mechanism of anticonvulsant effect has not been fully established. It may involve potentiation of GABAergic functions, N-methylD-aspartate (NMDA) inhibition, reduction of $\gamma$ hydroxybutyrate release, and blockade of voltagedependent sodium currents. ${ }^{26}$ Of note, IV VPA does not require organic solvents for dissolution, thus minimising the risk of injection site reactions such as 'purple glove'. It can be injected at a physiological $\mathrm{pH}$ and is not incompatible with other commonly used IV solutions. It is a broad-spectrum AED that can be used effectively in virtually all types of seizure, and safely in patients whose seizure type is poorly characterised. ${ }^{25}$ The mean efficacy of VPA has been reported to be $70 \%$ to $76 \%$ in more than 800 patients with SE. ${ }^{23,25}$ The response rate was better in children than in adults and did not differ between the SE types. The effective loading doses vary across different studies. A dose of $40 \mathrm{mg} / \mathrm{kg}$ (maximum, $3000 \mathrm{mg}$ ) can be given over 5 to 10 minutes. ${ }^{27}$

Safety studies have reported a $<10 \%$ overall incidence of adverse events. The reported sideeffects were mainly dizziness, thrombocytopenia and mild hypotension, independent of infusion rate. It was well tolerated even at high doses and fast infusion rates up to $30 \mathrm{mg} / \mathrm{kg}$ at $10 \mathrm{mg} / \mathrm{kg} / \mathrm{min}$ with little cardiorespiratory side-effects. High doses of IV VPA, however, are more likely to cause hyperammonaemia that may be dangerous in susceptible patients, eg young children with undiagnosed underlying metabolic diseases. There is also a risk of hepatic and pancreatic toxicity, and VPA encephalopathy. ${ }^{23,25}$

\section{Levetiracetam}

The drug LEV is currently licensed as monotherapy for the treatment of partial-onset seizures with and without secondary generalisation and as add-on therapy for myoclonic and primary generalised tonicclonic seizures. Intravenous LEV is currently approved by the United States Food and Drug Administration as an adjunctive treatment in patients aged $\geq 16$ years as an AED when oral therapy is not tolerated. ${ }^{28,29}$

Of note is that LEV is characterised by a linear pharmacokinetic profile with less than $10 \%$ protein binding and no hepatic metabolism. With twice daily infusion, a steady state can be achieved within 48 hours. Approximately $60 \%$ of the drug is excreted unchanged by the kidneys, and its plasma half-life is reported to be between 6 and 8 hours. It has a low risk of systemic side-effects and drug-drug interactions. ${ }^{29}$ Acutely applied LEV may preferentially modulate neuronal activity by inhibition of intracellular $\mathrm{Ca}^{2+}$ increase, delayed rectifier $\mathrm{K}^{+}$currents, $\mathrm{Cl}^{-} / \mathrm{HCO}_{3}^{-}$ exchanger, and AMPA-receptors. ${ }^{30}$

In a recent meta-analysis, the mean efficacy was $68.5 \%$ in 234 patients with SE (95\% confidence interval, $56.2 \%-78.7 \%) .{ }^{23} \mathrm{~A}$ dose of LEV up to 60 $\mathrm{mg} / \mathrm{kg}$ (maximum, $4500 \mathrm{mg}$ ) could be given over 10 minutes in established SE. ${ }^{27}$

From the available evidence and clinical experience, IV VPA or LEV can both be considered an alternative to phenytoin in benzodiazepine-resistant $\mathrm{SE}$, ie established SE. Input from neurologists will be helpful in subsequent management.

The ongoing Established Status Epilepticus Treatment Trial (NCT 01960075) is an international, multicentre study that is designed to find out the most effective and/or least effective treatment of established SE among patients older than 2 years by comparing three treatment arms: fosphenytoin, LEV, and valproic acid. It is hoped that the results can provide better guidance for our management.

\section{Refractory status epilepticus}

When seizures continue despite benzodiazepine and one other AED, it becomes refractory, regardless of the elapsed time. Patients with RSE are typically comatose or have a decreased consciousness level, and have cardiopulmonary compromise. They are best managed in an intensive care facility. The most commonly used continuous infusions are midazolam, propofol, and thiopentone. Currently there is insufficient evidence to recommend any one particular agent. ${ }^{31}$ Intensive care support is preferable at this stage of management.

Midazolam has a rapid onset of action and is easily titrated. Its main disadvantage is the development of tachyphylaxis with prolonged infusion. ${ }^{32} \mathrm{~A}$ recent report suggested that use of a higher infusion rate is associated with a reduction in seizure recurrence within 48 hours of discontinuation. ${ }^{33}$

Propofol has an onset of action within 3 to 5 minutes, and its half-life is only 5 to 10 minutes. The main concern with its use is development of propofol-related infusion syndrome, a rare but potentially lethal complication with dysrhythmia, heart failure, hyperkalaemia, hypertriglyceridaemia, metabolic acidosis, and rhabdomyolysis. Propofol infusion with dose exceeding $5 \mathrm{mg} / \mathrm{kg} / \mathrm{h}$ is not recommended for $>48$ hours, especially in children. ${ }^{34}$ Propofol is associated with less tachyphylaxis and less hypotension than midazolam and thiopentone, respectively.

Thiopentone infusion has been used in RSE for over 50 years and is associated with a lower frequency of treatment failure. Its side-effects, however, include significant hypotension requiring pressors, prolonged mechanical ventilation, 
allergic reaction, long half-life (15-50 hours), and immunosuppression.

Electroencephalogram (EEG) is essential when monitoring the effects of anaesthetics in the treatment of RSE. Although the primary goal of treatment is seizure control, the optimal extent of EEG suppression remains controversial: seizure suppression, burst suppression, or flat recording. There is no evidence from either prospective or retrospective studies to suggest an 'adequate' effect. ${ }^{35}$ Critical care continuous EEG monitoring is recommended to monitor the efficacy of continuous infusions of midazolam, propofol, or thiopentone. It can confirm seizure cessation and absence of seizure recurrence. Concurrent video recording is also strongly recommended as a supplement to clinical examination. If available, the EEG recording should be initiated as soon as possible after treatment of RSE, be continued until seizures are controlled for at least 24 hours, and preferably be continued for another 24 hours after the agent is withdrawn. Nonconvulsive seizures are common after treatment of convulsive seizures, both in adults and children. ${ }^{36,37}$ Seizures may also recur despite EEG-confirmed burst suppression or complete suppression of background seizures, such that intermittent recording may not be adequate. ${ }^{31}$ Ideally the recording should also be reviewed periodically, at least twice daily. Nonetheless, such intensive EEG monitoring is currently not feasible in most settings and we should consider offering the most pragmatic level of care that resources allow. ${ }^{38}$ There are no studies to suggest the optimal duration and weaning of anaesthetic infusion although most experts would agree that continuing the infusion for approximately 24 hours after controlling the seizures and weaning over 6 to 12 hours is a reasonable regimen. ${ }^{39}$

Recently there have been reports to suggest that use of anaesthetic coma in patients might be associated with prolonged hospital stay, higher infection rates, and increased mortality. Both Sutter et $\mathrm{al}^{40}$ and Marchi et $\mathrm{a}^{41}$ reported similar findings and there was at best Class III evidence that patients treated with therapeutic coma had a poorer outcome, independent of possible confounders. Nonetheless both studies were retrospective and were performed at a single tertiary centre where subjects were non-randomised and managed according to current guidelines. There remain many unanswered questions regarding use of anaesthetic agents in SE. ${ }^{42}$ Meanwhile we should carefully and individually balance the risks and benefits of using anaesthetic agents to treat patients with RSE.

\section{Super-refractory status epilepticus}

The term SRSE was first used in the Third LondonInnsbruck Colloquium on Status Epilepticus held in Oxford on 7-9 April 2011. ${ }^{4}$ It is an uncommon but challenging condition to manage. Current management is based mainly on case series and expert opinion. ${ }^{39}$ Treatment aims in SRSE include: (1) establishing and treating underlying causes where feasible, (2) controlling the seizures, (3) neuroprotection, and (4) avoiding or treating systemic complications associated with prolonged

TABLE. Investigations in status epilepticus ${ }^{45}$

\begin{tabular}{|c|c|}
\hline Investigation & Descriptions \\
\hline Basic investigations: in all patients & $\begin{array}{l}\text { - Fingerprick glucose } \\
\text { - Vital signs (ABC: airway, breathing, circulation, etc) } \\
\text { - Computed tomography of brain } \\
\text { - Laboratory tests: blood glucose, renal and liver function tests, calcium, magnesium, drug levels } \\
\text { (where appropriate) } \\
\text { - Electroencephalogram }\end{array}$ \\
\hline $\begin{array}{l}\text { Further investigations: based on clinical } \\
\text { history and examination }\end{array}$ & $\begin{array}{l}\text { - Cerebrospinal fluid for infection } \\
\text { - Toxicology screen } \\
\text { - Blood gases } \\
\text { - Thyroid function/antithyroglobulin and antiperoxidase antibodies } \\
\text { - Metabolic screen } \\
\text { - Infection screen } \\
\text { - Magnetic resonance imaging (of brain) } \pm \text { contrast }\end{array}$ \\
\hline $\begin{array}{l}\text { Other investigations to be considered (not } \\
\text { exhaustive) }\end{array}$ & $\begin{array}{l}\text { - Autoimmune encephalitis }{ }^{45} \text { (blood } \pm \text { cerebrospinal fluid) for NMDAR, VGKC (LGl1, Caspr2), } \\
\text { - AMPAR, GABA-B, mGluR5, GAD65, VGCC type N or P/Q, gAChR, DPPX, etc } \\
\text { - Cerebrospinal fluid for cytology } \\
\text { - Vasculitis screen (ANA, dsDNA, C3/C4, ANCA, etc) } \\
\text { - UncG gene } \pm \text { other mitochondrial diseases } \\
\text { Uncommon infections: scrub typhus, mycoplasma pneumonia, HIV, syphilis, etc }\end{array}$ \\
\hline
\end{tabular}

Abbreviations: AMPAR = $\alpha$-amino-3-hydroxy-5-methyl-4-isoxazolepropionic acid receptor; $A N A=$ anti-nuclear antibody; $A N C A=$ anti-neutrophil cytoplasmic antibodies; Caspr2 = contactin-associated protein-like 2; DPPX = dipeptidyl-peptidase-like protein-6; dsDNA = double-stranded DNA; GABA-B = $\gamma$-aminobutyric acid-B; gAChR = neuronal ganglionic nicotinic acetylcholine receptor; GAD65 = glutamic acid decarboxylase 65; HIV = human immunodeficiency virus; LGII = leucine-rich glioma inactivated protein l; mGluR5 = metabotropic glutamate receptor 5; NMDAR = N-methyl-D-aspartate receptor; VGCC = voltage-gated calcium channel; VGKC = voltage-gated potassium channel 
anaesthesia.

The underlying cause is by far the most significant factor in determining the outcome of SRSE. Besides basic investigations, other uncommon causes may need to be considered, especially because some may have therapeutic implications. Such causes include: (1) immune-mediated diseases, (2) mitochondrial diseases, (3) uncommon infective disorders, (4) genetic disorders, and (5) drugs and toxins. Lists of these conditions are found in other reviews. $^{43,44}$ A brief summary of important investigations is shown in the Table. ${ }^{45}$ Regarding the maintenance AEDs, Shorvon and Ferlisis ${ }^{39}$ recommended: (1) polytherapy with two AEDs at high doses, (2) avoiding frequent switching of drugs, (3) preferably choosing drugs with low interaction potential and no renal/hepatic toxicity, and (4) avoiding GABAergic AEDs.

The importance of recognising the underlying aetiology in overall management cannot be overemphasised. The prototype example is the increasing reports of autoimmune causes in de-novo-onset SRSE. ${ }^{45}$ There is increasing recognition of potential pathogenicity of various cell surface antigen autoantibodies in patients with acute onset of epilepsy. Thus, a high index of suspicion is essential for diagnosis. Many of these antibody tests are not available locally and results take weeks to return. Empirical therapy with immune-modulatory treatment (methylprednisolone, IV immunoglobulin, and/or plasma exchange) may be considered, especially if the patient has evidence of central nervous system inflammation on cerebrospinal fluid (ie elevated protein, pleocytosis and/or oligoclonal bands) or on magnetic resonance brain scan (ie mesial temporal or parenchymal fluid-attenuated inversion recovery/T2-weighted hyperintensity). Supportive clinical features include viral prodrome,

\begin{tabular}{|c|c|}
\hline $\begin{array}{l}\text { 1st stage: } \\
\text { early SE }\end{array}$ & $\begin{array}{l}\text { Benzodiazepines as one of the following first-line options } \\
\text { May repeat once, consider second antiepileptic drug if necessary: } \\
\text { - intravenous lorazepam ( } 0.1 \mathrm{mg} / \mathrm{kg} / \mathrm{dose} \text {, max: } 4 \mathrm{mg} / \mathrm{dose}) \text { OR } \\
\text { - intravenous diazepam ( } 0.15-0.2 \mathrm{mg} / \mathrm{kg} / \mathrm{dose}, \mathrm{max}: 10 \mathrm{mg} / \mathrm{dose}) \\
\text { If venous accesses are not available, consider one of the following: } \\
\text { - rectal diazepam }(0.2-0.5 \mathrm{mg} / \mathrm{kg}, \mathrm{max}: 20 \mathrm{mg} / \mathrm{dose}) \text { OR } \\
\text { - intramuscular midazolam (max: } 10 \mathrm{mg} / \text { dose) OR } \\
\text { - buccal midazolam } 5-10 \mathrm{mg}\end{array}$ \\
\hline $\begin{array}{c}\text { 2nd stage: } \\
\text { ESE }\end{array}$ & $\begin{array}{l}\text { There is no evidence to support which is the preferred therapy } \\
\text { Choose one of the following options as a single dose: } \\
\text { - intravenous phenytoin ( } 15-20 \mathrm{mg} / \mathrm{kg} \text {, max rate: } 50 \mathrm{mg} / \mathrm{min} \text {; slow injection or diluted only in } \\
\text { saline) OR } \\
\text { - intravenous valproic acid ( } 40 \mathrm{mg} / \mathrm{kg} \text {, max: } 3000 \mathrm{mg} / \mathrm{dose} \text { infuse over } 5-10 \mathrm{mins}) \text { OR } \\
\text { - intravenous levetiracetam }(60 \mathrm{mg} / \mathrm{kg}, \max : 4500 \mathrm{mg} / \mathrm{dose} \text { infuse over } 10 \mathrm{mins}) \text { OR } \\
\text { - intravenous phenobarbitone }(15 \mathrm{mg} / \mathrm{kg}, \max \text { rate: } 100 \mathrm{mg} / \mathrm{min})\end{array}$ \\
\hline $\begin{array}{c}\text { 3rd stage: } \\
\text { RSE }\end{array}$ & $\begin{array}{l}\text { There is no clear evidence to guide therapy in this stage } \\
\text { Intensive care support is desirable; EEG monitoring is recommended } \\
\text { - midazolam } 0.1-0.2 \mathrm{mg} / \mathrm{kg} \text {, followed by infusion } 0.05-3 \mathrm{mg} / \mathrm{kg} / \mathrm{h} \text { OR } \\
\text { - propofol } 3-5 \mathrm{mg} / \mathrm{kg} \text {, followed by infusion } 2-15 \mathrm{mg} / \mathrm{kg} / \mathrm{h} \mathrm{OR} \\
\text { - thiopentone } 2-3 \mathrm{mg} / \mathrm{kg} \text {, followed by infusion } 3-5 \mathrm{mg} / \mathrm{kg} / \mathrm{h}\end{array}$ \\
\hline $\begin{array}{l}\text { 4th stage: } \\
\text { SRSE }\end{array}$ & $\begin{array}{l}\text { There is no good clinical evidence of management in this stage } \\
\text { Consider use of the following: } \\
\text { - ketamine } 1-3 \mathrm{mg} / \mathrm{kg} \text {, followed by continuous infusion of up to } 5 \mathrm{mg} / \mathrm{kg} / \mathrm{h} \\
\text { - immunologic therapy-methylprednisolone } 1 \mathrm{~g} / \mathrm{d} \text { for } 3-5 \text { days } \pm \text { further taper }{ }^{46,53} \mathrm{OR} \\
\text { intravenous immunoglobulin } 0.4 \mathrm{~g} / \mathrm{kg} / \mathrm{d} \text { for } 5 \text { days OR plasma exchange } \\
\text { - ketogenic diet } \\
\text { - magnesium infusion: } 2-6 \mathrm{~g} / \mathrm{h} \text { to obtain serum level of } 3.5 \mathrm{mmol} / \mathrm{L}^{49} \\
\text { - pyridoxine injection in young children } \\
\text { - hypothermia } \\
\text { - electroconvulsive therapy } \\
\text { - epilepsy surgery }\end{array}$ \\
\hline
\end{tabular}

FIG. Updated algorithm for management of convulsive status epilepticus ${ }^{27,46,49,53}$

Abbreviations: ESE = established status epilepticus; RSE = refractory status epilepticus; SE = status epilepticus; SRSE = superrefractory status epilepticus 
antecedent psychiatric symptoms, and a history of systemic autoimmunity. ${ }^{46}$

Treatment of SRSE remains a challenge for clinicians. Various options have been tried in case reports/case series to minimise prolonged use of anaesthetic agents. Ketamine, a non-competitive antagonist of the NMDA glutamate receptor, has demonstrated its antiepileptic properties in clinical studies and it is not associated with significant cardiovascular depression. Clinical experience in case series also supports its efficacy. Response to ketamine was shown to be better when used as a third- or fourth-line agent rather than late in the course of SRSE and when the maintenance dose was greater than $0.9 \mathrm{mg} / \mathrm{kg} / \mathrm{h} .{ }^{47}$

Intravenous magnesium has also been used in SRSE, even in the absence of evidence of hypomagnesaemia. Its antiepileptic effect, however, has not been consistently supported in an experimental setting. A recent review found reports of use in 28 non-eclamptic patients in whom magnesium stopped SE in half. Adverse events of limb weakness and heart block were documented in three patients. Its possible role in SRSE, therefore, remains to be defined. ${ }^{48}$

A ketogenic diet has also been used in SRSE. It has been used in paediatric patients for many years. Its use in adult SE also appears promising. In a multicentre retrospective study of 10 adult patients, $90 \%$ of patients achieved ketosis, and SE ceased in a median of 3 days in all patients who achieved ketosis. ${ }^{49}$ Prospective trials are warranted to examine the efficacy of a ketogenic diet in adults with RSE. ${ }^{49}$ Other management modalities that include hypothermia, electroconvulsive therapy, and epilepsy surgery are still under investigation with variable success rate..$^{50-52}$

An updated algorithm for the overall management of SE is summarised in the Figure..$^{27,46,49,53}$

\section{Conclusion}

Convulsive SE-from established SE, RSE, to SRSE-remains a challenging condition to manage. The heterogeneous aetiology, presentation, natural history, and outcome increase the difficulty in performing randomised clinical trials that satisfy contemporary standards. The RAMPART study demonstrated non-inferiority of IM midazolam in early SE. In addition, VPA and LEV have also emerged as possible alternatives for phenytoin in established SE. The potential role of lacosamide in this stage of SE remains to be defined. Management of RSE and SRSE remains mostly non-evidencebased. Increasing international collaboration is important to better understand the condition. The new definition of SE from ILAE may also help to limit the methodological heterogeneity by unifying definitions and stages.

\section{Acknowledgement}

This project was supported in part by an unrestricted grant of The Hong Kong Epilepsy Society.

\section{Disclaimer}

This review is designed to assist clinicians by providing an analytical framework for evaluating and treating patients with convulsive status epilepticus. It is not intended to replace a clinician's medical judgement, or establish a protocol for all patients. The clinical conditions contemplated by this algorithm will not apply to nor work with all patients.

\section{References}

1. Guideline Development Group, Hong Kong Epilepsy Society. The Hong Kong epilepsy guideline 2009. Hong Kong Med J 2009;15 Suppl 5:6S-28S.

2. Gastaut H. Clinical and electroencephalographical classification of epileptic seizures. Epilepsia 1970;11:10213

3. Trinka E, Cock H, Hesdorffer D, et al. A definition and classification of status epilepticus-Report of the ILAE Task Force on Classification of Status Epilepticus. Epilepsia 2015;56:1515-23.

4. Shorvon S, Trinka E. Status epilepticus-making progress. Epilepsia 2011;52 Suppl 8:1-2.

5. Sutter R, Semmlack S, Kaplan PW. Nonconvulsive status epilepticus in adults-insights into the invisible. Nat Rev Neurol 2016;12:281-93.

6. Alldredge BK, Gelb AM, Isaacs SM, et al. A comparison of lorazepam, diazepam, and placebo for the treatment of outof-hospital status epilepticus. N Engl J Med 2001;345:6317.

7. Silbergleit R, Durkalski V, Lowenstein D, et al. Intramuscular versus intravenous therapy for prehospital status epilepticus. N Engl J Med 2012;366:591-600.

8. Prasad K, Al-Roomi K, Krishnan PR, Sequeira R. Anticonvulsant therapy for status epilepticus. Cochrane Database Syst Rev 2005;(4):CD003723.

9. Chamberlain JM, Okada P, Holsti M, et al. Lorazepam vs diazepam for pediatric status epilepticus: a randomized clinical trial. JAMA 2014;311:1652-60.

10. Navarro V, Dagron C, Elie C, et al. Prehospital treatment with levetiracetam plus clonazepam or placebo plus clonazepam in status epilepticus (SAMUKeppra): a randomised, double-blind, phase 3 trial. Lancet Neurol 2016;15:47-55.

11. Misra UK, Kalita J, Maurya PK. Levetiracetam versus lorazepam in status epilepticus: a randomized, open labeled pilot study. J Neurol 2012;259:645-8.

12. Chin RF, Neville BG, Peckham C, Wade A, Bedford H, Scott RC. Treatment of community-onset, childhood convulsive status epilepticus: a prospective, population-based study. Lancet Neurol 2008;7:696-703.

13. Jacob TC, Moss SJ, Jurd R. GABA receptor trafficking and its role in the dynamic modulation of neuronal inhibition. Nat Rev Neurosci 2008;9:331-43.

14. Treiman DM, Meyers PD, Walton NY, et al. A comparison of four treatments for generalized convulsive status epilepticus. Veterans Affairs Status Epilepticus Cooperative Study Group. N Engl J Med 1998;339:792-8. 
15. Olsen KB, Taubøll E, Gjerstad L. Valproate is an effective, well-tolerated drug for treatment of status epilepticus/serial attacks in adults. Acta Neurol Scand Suppl 2007;187:51-4.

16. Timakao S, Sawanyawisuth K, Chancharoen A. The efficacy of intravenous sodium valproate and phenytoin as the first-line treatment in status epilepticus: a comparison study. BMC Neurol 2013;13:98.

17. Peters CN, Pohlmann-Eden B. Intravenous valproate as an innovative therapy in seizure emergency situations including status epilepticus-experience in 102 adult patients. Seizure 2005;14:164-9.

18. Agarwal P, Kumar N, Chandra R, Gupta G, Antony AR, Garg N. Randomized study of intravenous valproate and phenytoin in status epilepticus. Seizure 2007;16:527-32.

19. Lee YJ, Yum MS, Kim EH, Ko TS. Intravenous levetiracetam versus phenobarbital in children with status epilepticus or acute repetitive seizures. Korean J Pediatr 2016;59:35-9.

20. Rossetti AO, Bromfield EB. Levetiracetam in the treatment of status epilepticus in adults: a study of 13 episodes. Eur Neurol 2005;54:34-8.

21. Atmaca MM, Orhan EK, Bebek N, Gurses C. Intravenous levetiracetam treatment in status epilepticus: a prospective study. Epilepsy Res 2015;114:13-22.

22. Mundlamuri RC, Sinha S, Subbakrishna DK, et al. Management of generalised convulsive status epilepticus (SE): a prospective randomised controlled study of combined treatment with intravenous lorazepam with either phenytoin, sodium valproate or levetiracetam-Pilot study. Epilepsy Res 2015;114:52-8.

23. Yasiry Z, Shorvon SD. The relative effectiveness of five antiepileptic drugs in treatment of benzodiazepineresistant convulsive status epilepticus: a meta-analysis of published studies. Seizure 2014;23:167-74.

24. Perucca E. Pharmacological and therapeutic properties of valproate: a summary after 35 years of clinical experience. CNS Drugs 2002;16:695-714.

25. Trinka E, Höfler J, Zerbs A, Brigo F. Efficacy and safety of intravenous valproate for status epilepticus: a systematic review. CNS Drugs 2014;28:623-39.

26. Löscher W. Basic pharmacology of valproate: a review after 35 years of clinical use for the treatment of epilepsy. CNS Drugs 2002;16:669-94.

27. Glauser T, Shinnar S, Gloss D, et al. Evidence-based guideline: treatment of convulsive status epilepticus in children and adults: report of the Guideline Committee of the American Epilepsy Society. Epilepsy Curr 2016;16:48-61.

28. Lang N, Esser W, Evers S, et al. Intravenous levetiracetam in clinical practice-Results from an independent registry. Seizure 2015;29:109-13.

29. Wright C, Downing J, Mungall D, et al. Clinical pharmacology and pharmacokinetics of levetiracetam. Front Neurol 2013;4:192.

30. Surges R, Volynski KE, Walker MC. Is levetiracetam different from other antiepileptic drugs? Levetiracetam and its cellular mechanism of action in epilepsy revisited. Ther Adv Neurol Disord 2008;1:13-24.

31. Claassen J, Hirsch LJ, Emerson RG, Mayer SA. Treatment of refractory status epilepticus with pentobarbital, propofol, or midazolam: a systematic review. Epilepsia 2002;43:14653.

32. Shafer A. Complications of sedation with midazolam in the intensive care unit and a comparison with other sedative regimens. Crit Care Med 1998;26:947-56.
33. Fernandez A, Lantigua $\mathrm{H}$, Lesch $\mathrm{C}$, et al. High-dose midazolam infusion for refractory status epilepticus. Neurology 2014;82:359-65.

34. Vasile B, Rasulo F, Candiani A, Latronico N. The pathophysiology of propofol infusion syndrome: a simple name for a complex syndrome. Intensive Care Med 2003;29:1417-25.

35. Rossetti AO, Lowenstein DH. Management of refractory status epilepticus in adults: still more questions than answers. Lancet Neurol 2011;10:922-30.

36. Claassen J, Mayer SA, Kowalski RG, Emerson RG, Hirsch LJ. Detection of electrographic seizures with continuous EEG monitoring in critically ill patients. Neurology 2004;62:1743-8.

37. Abend NS, Wusthoff CJ, Goldberg EM, Dlugos DJ. Electrographic seizures and status epilepticus in critically ill children and neonates with encephalopathy. Lancet Neurol 2013;12:1170-9.

38. Herman ST, Abend NS, Bleck TP, et al. Consensus statement on continuous EEG in critically ill adults and children, part I: indications. J Clin Neurophysiol 2015;32:87-95.

39. Shorvon S, Ferlisi M. The treatment of super-refractory status epilepticus: a critical review of available therapies and a clinical treatment protocol. Brain 2011;134(Pt 10):2802-18.

40. Sutter R, Marsch S, Fuhr P, Kaplan PW, Rüegg S. Anesthetic drugs in status epilepticus: risk or rescue? A 6-year cohort study. Neurology 2014;82:656-64.

41. Marchi NA, Novy J, Faouzi M, Stähli C, Burnand B, Rossetti AO. Status epilepticus: impact of therapeutic coma on outcome. Crit Care Med 2015;43:1003-9.

42. Sutter R. Kaplan PW. Can anesthetic treatment worsen outcome in status epilepticus? Epilepsy Behav 2015;49:2947.

43. Tan RY, Neligan A, Shorvon SD. The uncommon causes of status epilepticus: a systematic review. Epilepsy Res 2010;91:111-22.

44. Trinka E, Hofler J, Zerbs A. Causes of status epilepticus. Epilepsia 2012;53 Suppl 4:127-38.

45. Davis R, Dalmau J. Autoimmunity, seizures, and status epilepticus. Epilepsia 2013;54 Suppl 6:46-9.

46. Toledano M, Pittock SJ. Autoimmune epilepsy. Semin Neurol 2015;35:245-58.

47. Gaspard N, Foreman B, Judd LM, et al. Intravenous ketamine for the treatment of refractory status epilepticus: a retrospective multicenter study. Epilepsia 2013;54:1498503.

48. Zeiler FA, Matuszczak M, Teitelbaum J, Gillman LM, Kazina CJ. Magnesium sulfate for non-eclamptic status epilepticus. Seizure 2015;32:100-8.

49. Thakur KT, Probasco JC, Hocker SE, et al. Ketogenic diet for adults in super-refractory status epilepticus. Neurology 2014;82;665-70.

50. Zeiler FA, Matuszczak M, Teitelbaum J, Gillman LM, Kazina CJ. Electroconvulsive therapy for refractory status epilepticus: a systematic review. Seizure 2016;35:23-32.

51. Zeiler FA, Zeiler KJ, Teitelbaum J, Gillman LM, West M. Therapeutic hypothermia for refractory status epilepticus. Can J Neurol Sci 2015;42:221-9.

52. Winkler PA. Surgical treatment of status epilepticus: a palliative approach. Epilepsia 2013;54 Suppl 6:68-71.

53. Trinka E, Hofler J, Leitinger M, Brigo F. Pharmacotherapy for status epilepticus. Drugs 2015;75:1499-521. 